JURNAL SYNTAX FUSION

Vol 2 No 02, Februari 2022

E-ISSN: 2775-6440 | P-ISSN: 2808-7208

Jurnal Homepage https://fusion.rifainstitute.com

\title{
PENGARUH STRES TERHADAP KESEJAHTERAAN PSIKOLOGIS MAHASISWA SELAMA PEMBELAJARAN JARAK JAUH DI MASA PANDEMI
}

\author{
Gusti Novia Nanda, Pramesti Pradna Paramita \\ Fakultas Psikologi, Universitas Airlangga, Indonesia \\ Email: Gusti.novia.nanda-2017@psikologi.unair.ac.id, \\ pramesti.paramita@psikologi.unair.ac.id
}

\begin{abstract}
Abstrak
Berdasarkan Surat Edaran Nomor 1 Tahun 2020 tentang Pencegahan Penyebaran Corona Virus Disease (COVID-19) di perguruan tinggi, selama masa pandemi COVID-19, Pimpinan Perguruan Tinggi Negeri (PTN) serta Lembaga Layanan Pendidikan Tinggi (LLDikti) diminta untuk menyesuaikan pelaksanaan kegiatan Tri Dharma Perguruan Tinggi dengan melakukan pembelajaran jarak jauh. Penelitian ini dilakukan pada mahasiswa di Perguruan Tinggi Negeri maupun Swasta dengan jumlah responden sebanyak 273 orang. Teknik pengumpulan data yang digunakan adalah snowball sampling. Berdasarkan hasil uji, nilai F adalah 26,593 dengan tingkat signifikansi sebesar 0,000 $<0,05$. Maka dari itu, dapat disimpulkan bahwa ada pengaruh antara variabel stres mahasiswa $(\mathrm{X})$ terhadap variabel kesejahteraan psikologis $(\mathrm{Y})$. Nilai koefisien determinasi $\left(\mathrm{R}^{2}\right)$ sebesar 0,089 , yang berarti variabel stres berpengaruh sebesar 8,9\% terhadap kesejahteraan psikologis mahasiswa, sedangkan $91,1 \%$ berasal dari variabel lain yang tidak diteliti. Diketahui pula nilai koefisien regresi sebesar $-1,48$, yang menyatakan bahwa setiap penambahan $1 \%$ nilai stres, maka nilai kesejahteraan psikologis berkurang sebesar -1,481. Maka dari itu, diharapkan mahasiswa dapat melakukan langkah preventif agar tidak mengalami stres selama pembelajaran jarak jauh, karena stres dapat menjadi salah satu penyebab terganggunya kesejahteraan psikologis.
\end{abstract}

Kata kunci: COVID-19, kesejahteraan psikologis, stres

\section{Abstract}

Based on Circular Number 1 of 2020 concerning the Prevention of the Spread of Corona Virus Disease (COVID-19) in universities, during the COVID-19 pandemic, leaders of State Universities (PTN) and Higher Education Service Institutions (LLDikti) were asked to adjust the implementation of the Tri Dharma College by conducting distance learning. Compared to the general population, university students are more vulnerable to mental health problems stemming from a pandemic due to the various changes taking place in the learning system. This study aims to determine whether student stress affects psychological well-being during distance learning during the COVID-19 pandemic. This research was conducted on students at public and private universities with a total of 273 respondents. The value of the

Copyright holder: Gusti Novia Nanda, Pramesti Pradna Paramita (2022)

DOI : $\quad$ https://doi.org/10.54543/fusion.v2i02.155

Published by : Rifa Institute 
coefficient of determination $\left(R^{2}\right)$ is 0.089 , which means that the stress variable has an effect of $8.9 \%$ on the psychological well-being of students, while $91.1 \%$ comes from other variables not examined. It is also known that the regression coefficient value is -1.48 , which states that for every $1 \%$ addition to the stress value, the psychological well-being value decreases by -1.481. Therefore, it is expected that students can take preventive steps so as not to experience stress during distance learning, because stress can be one of the causes of disruption of psychological wellbeing.

Keywords: COVID-19, psychological well-being, stress

Diserahkan: 12-01-2022 Diterima: 25-01-2022 Diterbitkan: 20-02-2022

\section{Pendahuluan}

Berdasarkan Surat Edaran Nomor 1 Tahun 2020 tentang Pencegahan Penyebaran Corona Virus Disease (COVID-19) di perguruan tinggi, selama masa pandemi COVID-19, Pimpinan Perguruan Tinggi Negeri (PTN) serta Lembaga Layanan Pendidikan Tinggi (LLDikti) diminta untuk menyesuaikan pelaksanaan kegiatan Tri Dharma Perguruan Tinggi. Peraturan mengenai tata kerja dan mekanisme yang mengalami penyesuaian antara lain proses belajar mengajar, penelitian, dan pengabdian (seperti Belajar Jarak Jauh, remote office, dan lain lain) (Kartini, 2021). Selain itu, kegiatan organisasi kemahasiswaan yang ikut serta khalayak ramai, baik di kampus maupun di luar kampus harus ditunda. Hal ini dikarenakan mahasiswa diwajibkan mengurangi mobilitas serta melakukan social distancing, self-detection, dan self-quarantine (Asmuni, 2020). Maka dari itu, seluruh kegiatan akademik termasuk sistem pembelajaran mahasiswa berubah menjadi pembelajaran jarak jauh.

Dibandingkan dengan populasi umum, mahasiswa mungkin lebih rentan terhadap masalah kesehatan mental yang berasal dari pandemi. Banyak penelitian internasional telah mengidentifikasi mahasiswa sebagai kelompok berisiko tinggi untuk kondisi kesehatan mental, terutama pada titik transisi kritis pendidikan mereka (Amiruddin, 2013). Selama COVID-19, mahasiswa menghadapi stresor diluar stres kesehatan, ekonomi, dan sosial umum yang berdampak pada hampir semua orang. Proses pembelajaran di universitas sangat terganggu ketika perkuliahan dipindahkan secara online. Mulai dari kehidupan kampus terhenti, pengalaman pribadi dan intelektual formatif direnggut, dan mahasiswa semakin putus asa tentang dampak pandemi pada pilihan karir masa depan mereka dalam ekonomi dunia yang lumpuh saat menghadapi pandemi COVID-19. Tidak mengherankan, mahasiswa menunjukkan tingkat depresi dan kecemasan yang lebih tinggi dibandingkan dengan populasi umum selama pandemi (Utomo, 2021).

Terdapat beberapa perubahan signifikan dalam pembelajaran jarak jauh yang dijalani oleh mahasiswa. Diantaranya adalah terhambat akses terhadap referensi yang tidak bisa dicari di internet (Basoeky et al., 2021). Banyak jurnal, buku, maupun penelitian sebelumnya yang hanya tersedia di perpustakaan. Dengan adanya pembelajaran jarak jauh, maka akses 
kepada sumber-sumber penting untuk menyelesaikan tugas, terutama skripsi, tentu akan sangat terbatas. Selanjutnya, jika mahasiswa memiliki hubungan yang kurang baik dengan keluarga, maka berada di rumah bisa membuat individu semakin merasa tertekan. Ketika individu semakin merasa tertekan maka kesejahteraan psikologis individu mulai terganggu (Muslim, 2020).

Kesejahteraan psikologis berperan penting dalam berbagai aspek kehidupan akademik dan non-akademik mahasiswa. Kesejahteraan psikologis adalah kemampuan individu untuk menerima diri apa adanya, membentuk hubungan yang erat dengan individu lain, mandiri, mampu mengontrol lingkungan eksternal, memiliki tujuan yang jelas dalam hidup, dan mampu merealisasikan potensi dalam diri secara berkelanjutan (Awaliyah \& Listiyandini, 2017). Ryff mengajukan model teoritis dari kesejahteraan psikologis, yang terdiri dari enam aspek berbeda dari positive functioning, yakni otonomi, penguasaan lingkungan, pertumbuhan pribadi, tujuan hidup, relasi positif dengan orang lain, dan penerimaan diri (Ryff, 1989).

Kesejahterawan psikologis mahasiswa juga berperan dalam menentukan pencapaian akademiknya. Mahasiswa dengan kesejahteraan psikologis yang baik akan memiliki prestasi akademik yang lebih baik pula (Pappa, 2019). Menurut Sahu, COVID-19 berdampak negatif kepada proses dan hasil belajar, serta kesejahteraan psikologis mahasiswa, termasuk gangguan pada emosi, mudah frustasi, kecemasan, serta kesepian (Sahu, 2020). Adapun berdasarkan pernyataan dari Nasrul, dkk. (2020), ketidakpahaman mahasiswa terhadap materi yang diajarkan, hambatan dalam jaringan, keluhan fisik seperti terlalu lama berada di depan layar, serta berkurangnya interaksi antar sesama mahasiswa menyebabkan kesejahteraan psikologis mahasiswa terganggu (Nasrul, 2020). Maka dari itu, dapat disimpulkan bahwa perubahan-perubahan yang signifikan selama pandemi memiliki peran dalam kesejahteraan psikologis mahasiswa.

Dalam proses pelaksanaannya, perkuliahan jarak jauh selama masa pandemi juga menimbulkan beberapa kendala. Banyak mahasiswa yang mengeluh karena kuliah berbasis daring membuat mereka kurang paham akan materi-materi perkuliahan yang disampaikan, dan pemberian tugas yang jumlahnya lebih banyak dibandingkan kuliah seperti biasa (Purna, 2020). Kendala-kendala pada mahasiswa yang menjalani pembelajaran jarak jauh dapat menimbulkan stressor yang kemudian memunculkan gejala-gejala stres pada mahasiswa. Stres merupakan kondisi tidak menyenangkan, yang kemudian menekan individu secara fisik dan psikologis, karena munculnya perubahan yang terjadi pada diri (Sitorus \& Maryatm, 2020).

Lazarus dan Folkman mendefinisikan stres sebagai hubungan tertentu antara individu dan lingkungan yang dinilai oleh individu tersebut membebani atau melebihi sumber dayanya dan membahayakan kesejahteraan psikologis (Lazarus \& Folkman, 1984). Menurut Atkinson, stres dapat mempengaruhi kemampuan individu dalam menghadapi lingkungannya. Apabila individu menerima permintaan berlebihan yang tidak dapat 
dipenuhi, maka stress akan muncul dan dapat mengancam kesejahteraan fisik dan psikologis (Atkinson et al., 2000).

Di Indonesia, memang sudah ada beberapa penelitian mengenai korelasi antara stres mahasiswa dan kesejahteraan psikologis selama pandemi COVID-19. Akan tetapi, masih belum ada penelitian yang mendalami tentang pengaruh tingkat stres terhadap kesejahteraan psikologis mahasiswa selama pandemi COVID-19. Maka dari itu, peneliti tertarik untuk meneliti pengaruh tingkat stres terhadap kesejahteraan psikologis mahasiswa selama pandemi COVID-19. Terdapat dua hipotesis dalam penelitian ini, yakni: Stres mahasiswa tidak berpengaruh terhadap kesejahteraan psikologis selama pembelajaran jarak jauh di masa pandemi COVID-19; atau stres mahasiswa memiliki pengaruh terhadap kesejahteraan psikologis selama pembelajaran jarak jauh di masa pandemi COVID-19.

\section{Metode Penelitian}

\section{Desain Penelitian}

Penelitian dilakukan dengan tipe penelitian kuantitatif. Pengumpulan data dengan instrumen penelitian, serta analisis data yang bersifat kuantitatif dilakukan dengan tujuan menguji hipotesis yang telah ditentukan oleh peneliti (Sugiyono, 2015). Penulis memilih menggunakan teknik pengumpulan data melalui survei. Penelitian dengan teknik pengumpulan data melalui survei ini melibatkan mahasiswa secara acak dari seluruh Indonesia untuk mengisi kuesioner melalui formulir secara daring yang telah disebar melalui media sosial (Neuman, 2007).

\section{Partisipan}

Teknik penelitian ini menggunakan metode non-probability sampling dengan teknik snowball sampling. Peneliti menggunakan pedoman Roscoe dalam Azwar dalam penentuan jumlah sampel. Menurut pedoman yang diusulkan oleh Roscoe, sampel dengan ukuran n>30 dan $\mathrm{n}<500$ sudah cukup untuk riset pada umumnya (Azwar \& Amalia, 2017).

Partisipan dalam penelitian ini adalah mahasiswa Perguruan Tinggi maupun Swasta diseluruh Indonesia, dengan rentang usia 18-25 tahun yang pernah atau sedang menjalani pembelajaran secara daring selama pandemi COVID-19. Partisipan dalam penelitian ini diberikan informed consent terlebih dahulu sebelum mengisi kuisioner, dan seluruh partisipan setuju untuk berpartisipasi dalam penelitian ini. Jumlah partisipan pada penelitian ini berjumlah 273 orang $\left(M_{\text {usia }}=19,73 ; S D_{\text {usia }}=1,604 ; 77,66\right.$ persen perempuan). Sebagian besar partisipan berusia 18-20 tahun dengan jumlah 176 orang $(64,47 \%), 21-23$ tahun dengan jumlah 93 orang $(34,07 \%)$, dan 4 orang berumur 24-25 tahun $(1,47 \%)$

\section{Pengukuran}

Dalam penelitian ini peneliti menggunakan 2 buah kuesioner untuk mengukur kedua variabel yang ingin diteliti. Kuesioner yang digunakan dalam penelitian ini ialah Ryff Scales of Psychological Well-Being (Ryff, 1989) dan The COVID-19 Student Stress Questionnaire (Zurlo, dkk., 2020). Ryff Scales of Psychological Well-Being merupakan instrumen yang 
didasarkan pada teori yang secara khusus berfokus pada pengukuran berbagai aspek kesejahteraan psikologis. Responden menilai pernyataan pada skala 1 sampai $6,(1=$ "sangat tidak setuju" dan 6 = "sangat setuju". Peneliti mengambil versi 9-item version, dengan total 54 butir, yang artinya terdapat 9 butir yang masing-masing mengukur satu konstruk dalam Ryff's Psychological Well-Being. Adapun untuk mengukur stres pada mahasiswa, alat ukur yang digunakan adalah COVID-19 Student Stress Questionnaire yang dioperasionalkan berdasarkan teori model transaksional dari Lazarus dan Folkman (1984) oleh Zurlo, dkk. (2020). Alat ukur The COVID-19 Student Stress Questionnaire dikembangkan dan divalidasi oleh Zurlo, dkk (2020) untuk memahami, mengidentifikasi secara komprehensif, dan menilai sumber stres tertentu yang menampilkan pengalaman terkait COVID-19 di kalangan mahasiswa. Alat ukur ini memiliki 7 butir pada skala Likert 5 poin $(1=$ "tidak stres sama sekali" dan 4 = "sangat stres").

Untuk menguji validitas alat ukur yang digunakan, penulis menggunakan skor validitas konten dari setiap aitem individual (i-CVI). Penulis meminta bantuan pada 4 ahli yang memberikan rating atau penilaian terhadap translasi atas aitem-aitem yang ada berdasarkan pada: tingkat relevansi, kepentingan, dan kejelasan. Setelah dilakukan uji validitas, tidak ada aitem yang perlu direvisi, sehingga pertanyaan pada setiap butir alat ukur dapat cukup jelas dipahami oleh partisipan. Berdasarkan hasil uji reliabilitas, diketahui bahwa reliabilitas alat ukur kesejahteraan psikologis adalah $(\alpha=0,801)$ dan untuk reliabilitas alat ukur stres mahasiswa adalah $(\alpha=0,850)$. Menurut Hinton, dkk (2004) alat ukur kesejahteraan psikologis dan stres mahasiswa dalam penelitian ini termasuk dalam kategori tinggi karena memiliki Crobach Alpha yang berada pada rentang 0,7 sampai dengan 0,9. Sehingga dapat disimpulkan bahwa, alat ukur yang digunakan dalam penelitian ini sudah reliabel untuk mengukur variabel-variabel penelitian.

Sebelum melakukan kebenaran hipotesis, peneliti melakukan beberapa uji asumsi terlebih dahulu, yaitu uji normalitas, uji linieritas, dan uji homoskesdastisitas. Pada uji grafik Normal P-P Plot (Normal Probability Plot), sebaran residual cenderung berkumpul mendekati garis diagonal. Maka dari itu, residual data dalam penelitian ini berdistribusi normal. Pada hasil uji linearitas, nilai signifikansi linearity pada kedua variabel sebesar 0,000 $<0,05$, dengan nilai signifikansi deviation from linearity sebesar 0,595 > 0,05. Maka dapat dikatakan bahwa variabel stres mahasiswa dan kesejahteraan psikologis selama pembelajaran jarak jauh di masa pandemi COVID-19 berhubungan linear secara signifikan. Adapun pada uji homoskesdastisitas, tidak terjadi pembentukan pola tertentu seperti bergelombang, melebar, ataupun menyempit. Hal tersebut mengindikasikan bahwa tidak terjadi heteroskedastisitas atau terjadi homoskedastisitas serta varians skor residual dan skor prediktif sama. Uji analisis ini menggambarkan bahwa data memenuhi persyaratan untuk pengujian model regresi.

Analisis Data 
Pengujian hipotesis dalam penelitian ini dianalisis dengan teknik statistik korelasi serta regresi dengan bantuan software SPSS versi 22 for windows. Sebelum itu, dilakukan analisis deskriptif untuk mengetahui gambaran data, serta uji asumsi klasik sebagai persyaratan uji regresi.

\section{Hasil Penelitian}

Peneliti mengkategorikan responden berdasarkan kelompok usia dan jenis kelamin. Dari 273 partisipan, sebanyak 176 partisipan $(64,47 \%)$ berusia 18-20 tahun, 93 partisipan $(34,07 \%)$ berusia $21-23$ tahun, dan 4 partisipan $(1,47 \%)$ berusia $24-25$ tahun. Partisipan yang berjenis kelamin perempuan berjumlah 212 orang $(77,66 \%)$, sedangkan laki-laki berjumlah 61 orang $(22,34 \%)$.

Penulis menggunakan penormaan yang mengacu pada penggolongan kategorisasi Azwar (2012). Kategorisasi dibagi menjadi tiga tingkat, yaitu tinggi, sedang, dan rendah. Pada variabel stres mahasiswa, partisipan yang tingkat stresnya berada pada kategori rendah sebanyak 51 orang (18,7\%), kategori sedang sebanyak 183 orang (67\%), dan kategori tinggi sebanyak 39 orang (14\%). Sama halnya dengan variabel kesejahteraan psikologis, jumlah partisipan yang berada pada kategori rendah pada variabel ini berjumlah 33 orang $(12,1 \%)$, kategori sedang sebanyak 201 orang $(73,6 \%)$, dan kategori tinggi sebesar 39 orang (14,3\%).

Untuk menguji tingkat kekuatan korelasi antarvariabel, penulis menggunakan kategorisasi tingkat kekuatan korelasi oleh Cohen 1988 (dalam Pallant, 2010). Nilai R yang menunjukkan korelasi antara variabel stres mahasiswa terhadap variabel kesejahteraan psikologis adalah 0,299, yang termasuk dalam kategori lemah.

Adapun berdasarkan tabel hasil uji, nilai $\mathrm{F}$ yang menunjukkan pengaruh antar dua variabel adalah 26,593 dengan tingkat signifikansi sebesar $0,000<0,05$ yang menunjukkan bahwa ada pengaruh antara variabel stres mahasiswa $(\mathrm{X})$ terhadap variabel kesejahteraan psikologis (Y).

Nilai R yang berguna menunjukkan kekuatan korelasi antara variabel independen dengan variabel dependen adalah 0,299. Apabila nilai $\mathrm{R}$ semakin mendekati 1, maka hubungan atau korelasi antara kedua varibel tersebut semakin kuat.

Selanjutnya nilai $R$ Square yang menunjukkan besarnya pengaruh variabel stres mahasiswa terhadap kesejahteraan psikologis adalah 0,089. Maka dari itu, variabel stres mahasiswa berpengaruh sebesar 8,9\% terhadap kesejahteraan psikologis, sedangkan 91,1\% berasal dari variabel lain yang tidak diteliti

Berdasarkan hasil dari uji regresi linear sederhana, nilai Constant (a) sebesar 242,116, sedangkan nilai stres (b/koefisien regresi) adalah -1,481. Sehingga kemudian didapatkan persamaan regresi $(\mathrm{Y}=242,116-1,481 \mathrm{X})$. Konstanta sebesar 242,116 mengandung arti bahwa nilai konsisten variabel kesejahteraan psikologis adalah sebesar 242,116. Adapun koefisien regresi sebesar -1,481 menyatakan bahwa setiap penambahan $1 \%$ nilai stres, maka nilai kesejahteraan psikologis berkurang sebesar -1,481. Koefisien regresi bernilai negatif, 
sehingga arah pengaruh variabel $\mathrm{X}$ terhadap $\mathrm{Y}$ adalah negatif. Hal ini menandakan bahwa semakin tinggi tingkat stres, maka akan berpengaruh kepada semakin rendahnya kesejahteraan psikologis yang dimiliki oleh mahasiswa.

\section{Pembahasan}

Penelitian ini bertujuan untuk mengetahui pengaruh stres terhadap kesejahteraan psikologis mahasiswa selama pembelajaran jarak jauh di masa pandemi COVID-19. Dari 273 responden yang memenuhi karakteristik peneliti, mayoritas adalah perempuan dengan rentang usia 18-20 tahun.

Berdasarkan hasil penelitian, variabel stres mahasiswa berpengaruh sebesar 8,9\% terhadap kesejahteraan psikologis, sedangkan $91,1 \%$ berasal dari variabel lain yang tidak diteliti. Walaupun hanya berpengaruh kecil terhadap kesejahteraan psikologis, namun stres pada mahasiswa tetap penting untuk diteliti. Proses stres sangat penting dalam berbagai bidang studi psikologis, karena sangat berdampak pada kesejahteraan psikologis dan perilaku mahasiswa.

Saat pandemi terjadi, terdapat beberapa perubahan dalam beberapa indikator. Indikator pertama adalah hubungan dan kehidupan akademik. Penutupan kampus dan perubahan tempat tinggal mahasiswa (apabila mahasiswa tersebut hidup merantau) dapat menyebabkan perubahan hubungan dengan kerabat, rekan kerja, dosen, serta studi akademis. Apabila mahasiswa tidak dapat beradaptasi dengan perubahan pada hubungan dan kehidupan akademik, maka mahasiswa akan merasa tertekan karena tidak dapat berhubungan secara intensif dengan kerabat dan orang-orang dalam lingkungan akademisnya.

Perubahan selanjutnya yang dialami mahasiswa selama pandemi adalah isolasi sosial. Isolasi sosial dapat mempengaruhi kesehatan mental dan kesejahteraan psikologis mahasiswa. Saat mejalani karantina sosial dirumah, maka mahasiswa akan cenderung kesepian karena harus jauh dari orang-orang yang disayangi. Adapun ketakutan terhadap penularan juga turut menjadi penyumbang stres mahasiswa. Bentuk ketakutan yang dialami mahasiswa selama pembelajaran jarak jauh adalah ketakutan bahwa orang terdekat akan terkominasi virus, serta ketakutan bahwa dirinya akan menjadi sumber penularan COVID19 kepada orang lain (hifzul Muiz \& Sumarni, 2020).

Menurut cognitive-relational theory oleh Lazarus \& Folkman (1984), stres adalah hubungan tertentu antara individu dan lingkungan yang dinilai oleh individu tersebut sebagai beban atau melebihi sumber dayanya dan membahayakan kesejahteraannya. Saat menghadapi stresor, penilaian terhadap stres (appraisal) ditentukan secara bersamaan dengan memahami tuntutan lingkungan dan sumber daya pribadi (resources). Appraisal dan resources dapat berubah dari waktu ke waktu karena efektivitas koping, persyaratan yang berubah, atau peningkatan kemampuan pribadi. Penilaian primer (primary appraisal) dicerminkan oleh penilaian sekunder (secondary appraisal) yang mengacu pada pilihan koping yang tersedia untuk menghadapi stres, yaitu sumber daya (resources) yang dirasakan 
individu untuk mengatasi tuntutan yang ada. Individu mengevaluasi kompetensi, dukungan sosial, dan materi atau sumber daya lainnya untuk menyesuaikan diri dengan keadaan, serta untuk membangun kembali keseimbangan antara individu dan lingkungan (Lazarus \& Folkman, 1984).

Dalam konteks pembelajaran jarak jauh yang dijalani oleh mahasiswa selama pandemi COVID-19, seluruh mahasiswa mengalami stressor yang sama, yaitu perubahanperubahan yang signifikan dalam konteks pembelajaran. Mahasiswa yang mampu beradaptasi dengan situasi ini merupakan mahasiswa yang terus mencoba menggali sumber daya (resources) yang dimilikinya untuk mengatasi tuntutan yang ada, sehingga jenis stres yang dialami oleh mahasiswa adalah eustres atau stres positif, yakni respon kognitif yang positif terhadap stressor. Saat mahasiswa mampu memanfaatkan resources yang dimilikinya dalam menghadapi stres, maka kesejahteraan psikologis mahasiswa akan tinggi, dan tingkat stresnya pun akan kian menurun. Hasilnya, mahasiswa akan menganggap stressor sebagai suatu hal yang menantang dan meningkatkan motivasi dalam menyelesaikan permasalahan.

Jika mahasiswa tidak mampu beradaptasi kepada berbagai perubahan yang dialami selama pandemi COVID-19 dan memanfaatkan resources yang dimiliki, perubahanperubahan ini akan dianggap sebagai stressor yang negatif, sehingga kesejahteraan psikologis mahasiswa terganggu. Terganggunya kesejahteraan psikologis pada mahasiswa dapat berdampak pada beberapa aspek dalam kehidupannya. Contoh dari rendahnya kesejahteraan psikologis individu ditandai dengan individu seringkali bergantung kepada penilaian dari orang lain untuk mengambil keputusan penting, merasa tidak mampu untuk berubah atau meningkatkan keadaan sekitar, merasa bosan dan tidak tertarik dengan diri kehidupan, terisolasi dan merasa frustrasi dalam hubungan interpersonal, tidak memiliki pandangan atau keyakinan yang memberi makna dalam hidupnya, serta tidak puas dengan dirinya sendiri (Ryff, 2013).

Menurut cognitive appraisal theory dari Lazarus dan Folkman (1984), stres psikologis dapat terjadi saat individu melihat tuntutan dari lingkungan sebagai ancaman terhadap kesejahteraan mereka sendiri. Menurut teori ini, peran lingkungan sangatlah berpengaruh terhadap kesejahteraan psikologis. Mahasiswa berada pada kondisi di mana mereka mengalami risiko yang nyata karena pandemi. Pencarian strategi koping untuk mengatasi permasalahan yang tengah dihadapi individu adalah reaksi adaptif spesifik yang dipilih selama penilaian sekunder. Penilaian sekunder muncul ketika individu menilai situasi yang sedang mereka hadapi sebagai sebuah peristiwa yang sulit, berbahaya atau berisiko. Salah satu strategi koping yang dapat digunakan adalah strategi koping yang berorientasi pada emosi (emotion-oriented coping strategies), yakni berusaha untuk mengurangi ketegangan dan emosi yang tidak menyenangkan akibat situasi yang memicu stres. Strategi koping yang berorientasi pada masalah (problem-focused coping) melibatkan upaya kognitif dan perilaku untuk mengurangi stres dengan mencoba memecahkan masalah (Lazarus \& 
Folkman, 1984). Dengan demikian, kondisi utama untuk keberfungsian yang tepat adalah mengembangkan strategi yang optimal untuk mengatasi stres.

Variabel stres mahasiswa berpengaruh sebesar 8,9\% terhadap kesejahteraan psikologis, sedangkan $91,1 \%$ berasal dari variabel lain yang tidak diteliti. Terdapat banyak faktor yang mempengaruhi tingkat kesejahteraan psikologis. Berbagai penelitian telah menghubungkan teori Erikson seperti pembentukan identitas, generativitas, dan integritas ego dengan kesejahteraan psikologis. Diseluruh penelitian ini, mereka yang melaporkan tingkat perkembangan ego yang lebih tinggi cenderung menunjukkan kesejahteraan yang lebih tinggi. Keberhasilan dalam melalui tugas-tugas perkembangan kehidupan dewasa juga memiliki kaitan dengan kesejahteraan psikologis yang lebih tinggi (Ferguson \& Goodwin, 2010).

Penelitian terdahulu yang menggunakan Teori Kepribadian Model Lima Besar (Big Five Model of Traits) juga menemukan bahwa aspek-aspek kepribadian memiliki kaitan dengan indikator-indikator dalam teori kesejahteraan psikologis Ryff. Banyak variabel perbedaan individu lainnya seperti optimisme, strategi manajemen kehidupan, kegiatan yang disengaja, empati, kecerdasan emosional, dan kemandirian adalah beberapa faktor yang dapat mempengaruhi kesejahteraan psikologis (Ryff, 2014). Optimisme, misalnya, memprediksi kesejahteraan psikologis yang lebih tinggi, dengan efek yang dimediasi oleh rasa kontrol. Harga diri yang stabil memprediksi skor yang lebih tinggi pada otonomi, penguasaan lingkungan dan tujuan hidup daripada harga diri yang tidak stabil (Paradise \& Kernis, 2002).

\section{Kesimpulan}

Hasil dari penelitian yang telah dilakukan peneliti ini menunjukkan bahwa stres mahasiswa memiliki pengaruh terhadap kesejahteraan psikologis selama pembelajaran jarak jauh di masa pandemi COVID-19. Adapun besarnya pengaruh variabel stres mahasiswa terhadap kesejahteraan psikologis sebesar $8,9 \%$, sedangkan $91,1 \%$ berasal dari variabel lain yang tidak diteliti.

Berdasarkan hasil penelitian dan keterbatasan yang dimiliki oleh peneliti, maka penelitian selanjutnya dapat menambahkan variabel lain yang diprediksi dapat memiliki pengaruh terhadap kesejahteraan psikologis mahasiswa selama pandemi dengan lingkup yang lebih luas dan beragam, seperti pengaruh dukungan sosial, resiliensi, ataupun kemampuan koping mahasiswa sebagai variabel antara. Untuk mahasiswa, disarankan untuk tetap terhubung secara sosial meskipun secara fisik jauh dari teman maupun kerabat terdekat. Dengan terhubung dengan orang terdekat, mahasiswa tetap akan terlibat dalam interaksi positif, mencari dan menerima dukungan sosial, serta membangun koneksi sosial. 


\section{BIBLIOGRAFI}

Amiruddin, R. (2013). Surveilans Kesehatan Masyarakat. PT Penerbit IPB Press. Google Scholar

Asmuni, A. (2020). Problematika Pembelajaran Daring di Masa Pandemi Covid-19 dan Solusi Pemecahannya. Jurnal Paedagogy, 7(4), 281-288. Google Scholar

Atkinson, C. T., Dusek, R. J., Woods, K. L., \& Iko, W. M. (2000). Pathogenicity of avian malaria in experimentally-infected Hawaii Amakihi. Journal of Wildlife Diseases, 36(2), 197-201. Google Scholar

Awaliyah, A., \& Listiyandini, R. A. (2017). Pengaruh rasa kesadaran terhadap kesejahteraan psikologis pada mahasiswa. Jurnal Psikogenesis, 5(2), 89-101. Google Scholar

Azwar, M., \& Amalia, R. (2017). Pemanfaatan jurnal elektronik sebagai sumber referensi dalam penulisan skripsi di Institut Pertanian Bogor. Google Scholar

Basoeky, U., Panggabean, S., Manu, G. A., Wardhana, A., Hoeronis, I., Adnan, Y., \& Sudirman, A. (2021). Pemanfaatan Teknologi Digital dalam Berbagai Aspek Kehidupan Masyarakat. Media Sains Indonesia. Google Scholar

Ferguson, S. J., \& Goodwin, A. D. (2010). Optimism and well-being in older adults: The mediating role of social support and perceived control. The International Journal of Aging and Human Development, 71(1), 43-68. Google Scholar

hifzul Muiz, M., \& Sumarni, N. (2020). Pengaruh Teknologi Pembelajaran Kuliah Online Di Era Covid-19 Dan Dampaknya Terhadap Mental Mahasiswa. EduTeach: Jurnal Edukasi Dan Teknologi Pembelajaran, 1(2), 153-165. Google Scholar

Kartini, E. (2021). Tantangan Dalam Pembelajaran Perguruan Tinggi Dan Implementasi Merdeka Belajar Di Masa Pandemi Covid-19. Journal Ilmiah Rinjani: Media Informasi Ilmiah Universitas Gunung Rinjani, 9(2), 43-50. Google Scholar

Lazarus, R. S., \& Folkman, S. (1984). Stress, appraisal, and coping. Springer publishing company. Google Scholar

Muslim, M. (2020). Manajemen stress pada masa pandemi covid-19. ESENSI: Jurnal Manajemen Bisnis, 23(2), 192-201. Google Scholar

Nasrul, D. F. (2020). Manajemen Waktu Belajar Di Perguruan Tinggi Pada Masa Pandemi Covid-19. Jieman, 2(2), 169-180. Google Scholar

Neuman, L. W. (2007). Social research methods, 6/E. Pearson Education India. Google Scholar

Pappa, L. (2019). Hubungan Antara Perilaku Prososial Dengan Kesejahteraan Psikologis Pada Mahasiswa. Universitas Mercu Buana Yogyakarta. Google Scholar

Paradise, A. W., \& Kernis, M. H. (2002). Self-esteem and psychological well-being: Implications of fragile self-esteem. Journal of Social and Clinical Psychology, 21(4), 
345-361. Google Scholar

Purna, R. S. (2020). Strategi Coping Stress Saat Kuliah Daring Pada Mahasiswa Psikologi Angkatan 2019 Universitas Andalas. Jurnal Psikologi Tabularasa, 15(1). Google Scholar

Ryff, C. D. (1989). Happiness is everything, or is it? Explorations on the meaning of psychological well-being. Journal of Personality and Social Psychology, 57(6), 1069. Google Scholar

Ryff, C. D. (2013). Eudaimonic well-being and health: Mapping consequences of selfrealization. Google Scholar

Ryff, C. D. (2014). Psychological well-being revisited: Advances in the science and practice of eudaimonia. Psychotherapy and Psychosomatics, 83(1), 10-28. Google Scholar

Sahu, P. (2020). Closure of universities due to coronavirus disease 2019 (COVID-19): impact on education and mental health of students and academic staff. Cureus, 12(4). Google Scholar

Sitorus, M. R., \& Maryatm, A. S. (2020). Hubungan Antara Harga Diri Dan Stres Dengan Psychological Well Being Pada Remaja Panti Asuhan Tanjung Barat Di Jakarta. IKRAITH HUMANIORA: Jurnal Sosial Dan Humaniora, 4(3), 1-18. Google Scholar

Sugiyono, S. (2015). Metode penelitian kombinasi. Bandung: Alfabeta. Google Scholar

Utomo, K. D. M. (2021). Pengaruh Dukungan Sosial dan Harapan terhadap Kesehatan Mental Selama Pandemi Covid-19. Seri Filsafat Teologi, 31(30), 290-298. Google Scholar

First publication right:
Jurnal Syntax Fusion: Jurnal Nasional Indonesia

This article is licensed under:

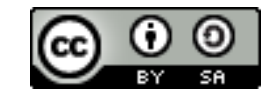

